\title{
The Effect of Calendarized Drug Package on Patients Compliance with Antibiotics
}

\author{
Ilil Maidatuz Zulfa ${ }^{1 *}$ (D), Widya Handayani ${ }^{2}$ \\ ${ }^{1}$ Department of Community and Management Pharmacy, Pharmacy Diploma, Akademi Farmasi Surabaya, Surabaya, East \\ Java, Indonesia; ${ }^{2}$ Department of Clinical Pharmacy, Akademi Farmasi Surabaya, Surabaya, East Java, Indonesia
}

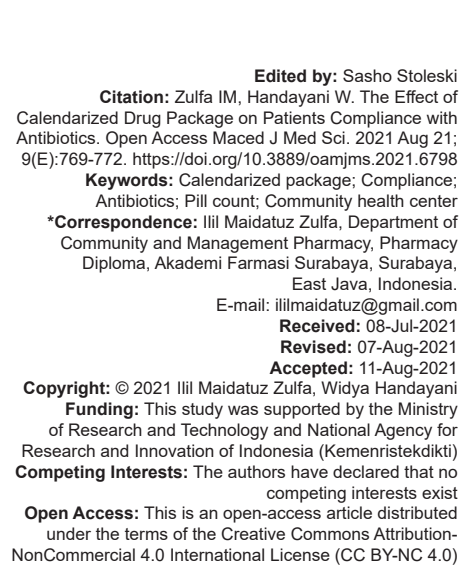

\section{Introduction}

Recently, the infectious disease still has a huge contribution to global deaths with 3.2 million mortality rates for lower respiratory tract infection and 1.4 million mortality rates for tuberculosis [1]. However, irrational and overuse of antibiotics can lead to the rise of bacterial resistance. Global Antimicrobial Surveillance System held by the World Health Organization stated that 500,000 people from 22 countries are exposed to bacterial resistance [2]. The increase of bacterial resistance has consequences to the excess of severity, morbidity, complication, and prolonged hospital stay [3]. One factor related to irrational antibiotics use is patients compliance [4].

Patients' compliance with antibiotics has been one of the global challenges in combating antibiotics resistance. Many factors such as forgetting and being too busy have been confirmed as causes of non-compliance [5]. Patients will tend to forget their antibiotics, especially when they feel better. Related to this phenomenon, the development of medication reminder media is essential. Several medication reminders have been applied in patients with a degenerative disease such as a calendarized blister, medication chart, pillbox, diary book. [6], [7], [8], [9]. Calendarized blister was successful in increasing the compliance and persistence in patients with hypertension. Moreover, medication charts, pillboxes, and diary books have been confirmed can help to improve compliance with patients with hypertension.

As far as observed, there is still a lack of data in applying medication reminder media for improving compliance in patients receiving antibiotics. Some studies implemented counseling and education to improve patients' compliance with antibiotics, and the results were variative [10], [11]. Therefore, this study was designed to develop and apply calendarized package as a medication reminder media in patients with short-course antibiotics to improve their compliance. 


\section{Materials and Methods}

\section{Materials}

\section{Calendarized package}

Calendarized package was prepared from the labeling of the original package of antibiotics with stickers. The stickers were designed for 7 days (written in Bahasa Indonesia) and five different times printed in different colors (Table 1). The stickers were applied to the original antibiotics package manually based on patients' prescriptions. Time stickers for antibiotics prescribed 3 times a day were set at 05.00, 13.00, and 21.00, while for antibiotics prescribed 2 times a day, the stickers were set at 06.00 and 18.00. For example, if patients are prescribed amoxicillin 3 times a day on Wednesday, subsequently, stickers will start on Wednesday and end on Saturday (Figure 1).

Table 1: Stickers design

\begin{tabular}{|c|c|c|c|c|}
\hline Days (in Indonesian) & Days (in English) & Sticker Design & Times & Sticker Design \\
\hline \multirow[t]{2}{*}{ Senin } & Monday & & 05.00 & \\
\hline & & Senin & & 05.00 \\
\hline \multirow[t]{2}{*}{ Selasa } & Tuesday & & 06.00 & \\
\hline & & Selasa & & 06.00 \\
\hline \multirow[t]{2}{*}{ Rabu } & Wednesday & & 13.00 & \\
\hline & & Rabu & & 13.00 \\
\hline \multirow[t]{2}{*}{ Kamis } & Thursday & & 18.00 & \\
\hline & & Kamis & & 18.00 \\
\hline \multirow[t]{2}{*}{ Jum'at } & Friday & & 21.00 & \\
\hline & & Jumat & & 21.00 \\
\hline \multirow[t]{2}{*}{ Sabtu } & Saturday & & & \\
\hline & & Sabtu & & \\
\hline \multirow[t]{2}{*}{ Minggu } & Sunday & & & \\
\hline & & Minggu & & \\
\hline
\end{tabular}

\section{Methods}

\section{Study design}

This was an experimental study conducted at four community health center in Surabaya (Puskesmas
Wonokromo, Puskesmas Kalirungkut, Puskesmas Gayungan, and Puskesmas Kedurus) from January to April 2021. The ethical approval was obtained from the Ethics Committee of Universitas Surabaya. Patients above 18 years old who were prescribed short-course oral antibiotics (not more than 7 days) during the study period were asked to participate in this study. Patients who agreed to participate would be asked to sign the informed consent and then classified into two groups using systematic random sampling. Patients who came first, third, fifth (odd number) were grouped into the control group, while those who arrived at second, fourth, and sixth (even number) were grouped into the intervention group. We did not interfere with the antibiotics prescription both in the intervention and control group. We calendarized the antibiotics package in the intervention group with the stickers while the control group received medication as a standard operational procedure at the community health center. Patients' demographical data, medications prescribed, and the last antibiotics course day was recorded. Patients were then contacted for compliance evaluation on the latest antibiotics course day.

\section{Compliance measurements}

Compliance measurements were conducted using the pill count method. Patients would be considered compliant if the remaining tablets counted not more than $15 \%$ of the total tablet prescribed [12]. However, because of the coronavirus disease 2019 (COVID-19) pandemic, the counting process could not be conducted directly. Therefore, we contacted patients on the last antibiotics course day and asked them to fill the online form and upload their remaining tablet pictures.

\section{Data analysis}

Baseline characteristic data such as the age, gender, educational background, and the average of drugs consumed were compared between two groups to confirm that there were no differences in

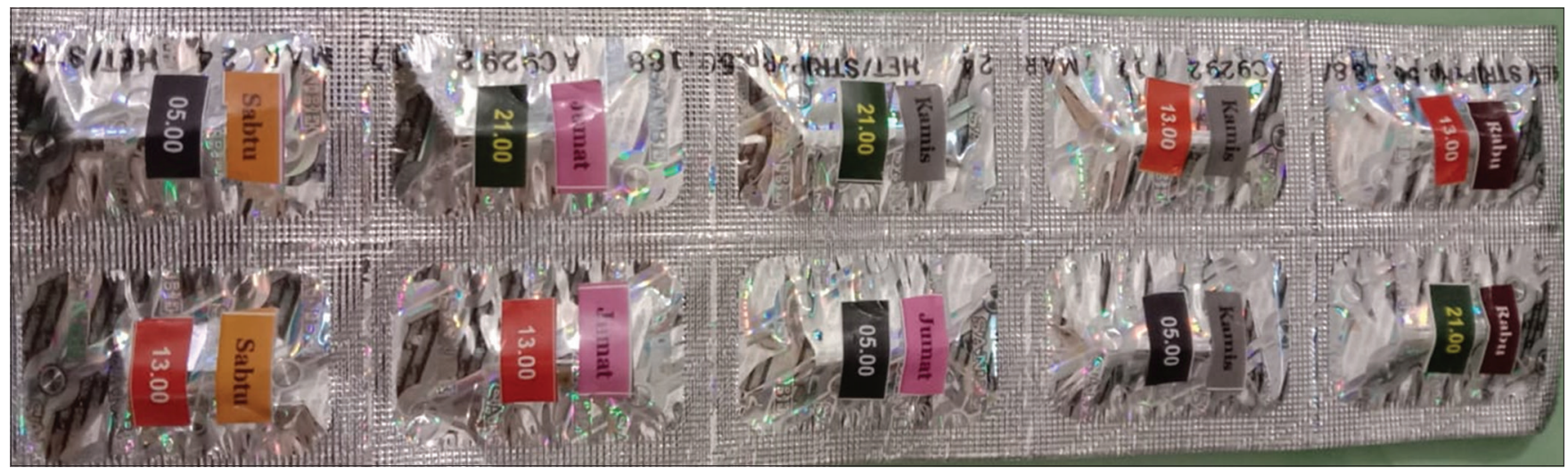

Figure 1: Stickers application on antibiotics package 
the factors that affected compliance. The number of compliant and non-compliant patients in both groups was analyzed using the Chi-square test. $p<0,05$ was considered statistically significant in the effect of the calendarized package on the patients' compliance with oral antibiotics.

\section{Results}

\section{Baseline characteristics}

A total of 150 patients who met the inclusion criteria were recruited in this study. Seventy-six patients were grouped into the intervention group, while the remaining 74 patients were the control group. All of the patients who joined in this study were received single short course antibiotics. The baseline characteristics of all patients were presented in Table 2, and the profile of antibiotics prescribed was illustrated in Figure 1.

Table 2: Baseline Characteristics

\begin{tabular}{|c|c|c|c|}
\hline \multirow[t]{2}{*}{ Characteristics } & \multirow{2}{*}{$\begin{array}{l}\text { Intervention Group } \\
n=76\end{array}$} & \multirow{2}{*}{$\begin{array}{l}\text { Control Group } \\
n=74\end{array}$} & \multirow[t]{2}{*}{$\mathrm{p}$-value } \\
\hline & & & \\
\hline \multicolumn{4}{|l|}{$\mathrm{Age}^{\star *}$} \\
\hline$<40$ & $61(53.20)$ & $44(51.80)$ & \multirow[t]{2}{*}{$0.005^{a}$} \\
\hline$>40$ & $15(22.80)$ & $30(22.20)$ & \\
\hline \multicolumn{4}{|l|}{ Gender** } \\
\hline Female & $50(65.79)$ & $42(56.76)$ & \\
\hline Male & $26(34.21)$ & $32(43.24)$ & $0.937^{\mathrm{a}}$ \\
\hline \multicolumn{4}{|l|}{ Education $^{\star *}$} \\
\hline Higher Education & $28(36.84)$ & $21(28.38)$ & \multirow[t]{2}{*}{$0.866^{a}$} \\
\hline Non-Higher Education & $48(63.16)$ & $53(71.62)$ & \\
\hline Number of drug consumed ${ }^{*}$ & $3.70 \pm 1.03$ & $3.60 \pm 1.00$ & $0.269^{\mathrm{b}}$ \\
\hline
\end{tabular}

Table 2 shows that there was no difference between the average number of drugs consumed and the distribution of gender and educational background $(p>0.05)$. However, in the distribution of age, there was a significant difference between the two groups $(p<0.05)$.

Figure 2 shows that both in the control and intervention groups, the most frequently prescribed antibiotic was amoxicillin with a dosage of $500 \mathrm{mg}$ 3 times a day. The other antibiotics prescribed were metronidazole $500 \mathrm{mg} 3$ times a day, ciprofloxacin

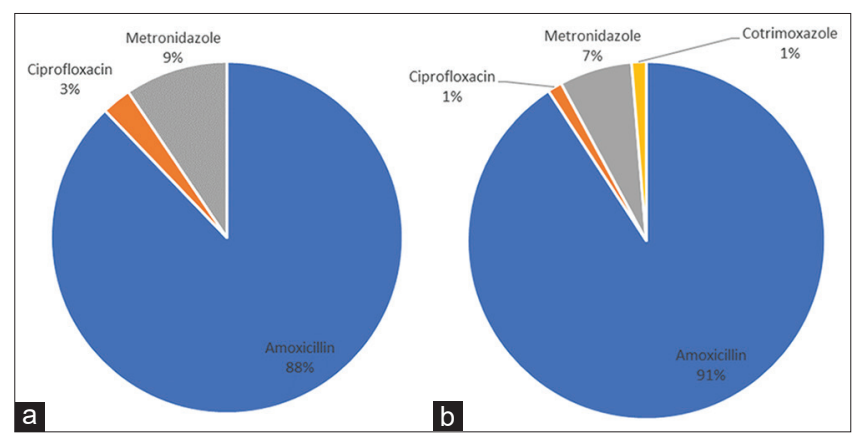

Figure 2: (a) Antibiotics prescribed in control group; (b) Antibiotics prescribed in intervention group
$500 \mathrm{mg} 2$ to 3 times a day, and cotrimoxazole $960 \mathrm{mg}$ 2 times a day.

\section{Patients compliance}

Patients' compliance was measured by counting the remaining antibiotics in the last day course. The distribution of compliance patients in both groups was presented in Table 3 below. The Analysis results demonstrated that the $p<0.005$. Consequently, the number of compliance patients between the two groups compared was statistically significant.

Table 3: Patients Compliance with Antibiotics

\begin{tabular}{llll}
\hline Groups & Compliance & Non-compliance & p-value \\
\hline Intervention Group $n=76$ & $55(72.37)$ & $21(27.63)$ & $0.002^{\mathrm{a}}$ \\
Control Group $\mathrm{n}=74$ & $34(45.95)$ & $40(54.05)$ & \\
\hline${ }^{*}$ Data presented in Average \pm SD; ${ }^{* *}$ Data presented in $\mathrm{n}(\%) ;{ }^{\mathrm{a}}$ Chi-square test.
\end{tabular}

${ }^{*}$ Data presented in Average $\pm \mathrm{SD}$; ${ }^{* *}$ Data presented in $\mathrm{n}(\%) ;{ }^{a}$ Chi-square test.

\section{Discussion}

Compliance is one of the concerns in controlling the rise of bacterial resistance. In addition, non-compliant with antibiotics therapy may also lead to therapeutic failure and reinfection [13]. Increasing antibiotics compliance will have a positive impact on treatment outcomes and also suppress bacterial resistance. Our analysis results indicated that calendarized package has a potential effect on the patients' compliance with antibiotics which showed in Table 3 . The number of compliant patients in the intervention group was higher than those in the control group. This finding could lead to additional tools in antibiotics prescription service. Day and time administration schedule on the packaging would help patients remember their antibiotics dosage and improve compliance.

As far as our observation, the concept of reminder packaging has not been applied to improving antibiotics compliance before. However, reminder or calendarized packaging has been confirmed on the improving of hypertensive patients' compliance. A previous study by Dupclay et al. stated that the use of reminder packaging had a positive role in consistent improvement in adherence and persistence of patients on an antihypertensive regimen [7]. Reminder or calendarized packaging might be a helpful tool for patients who likely to forget their therapeutics dosage. A study by Schneider et al. showed that daily dose blister packaging (pill-calendar) helped elderly patients remember their medication. It was proved by their higher medication possession ratios $(p=0.04)$ and lower diastolic blood pressure $(p=0.01)$ than patients who used traditional bottles [14]. The same reason might underlie the results of this study. Patients receiving antibiotics often miss their dosage because of simply forgetting [15]. 
The findings in this study indicate a potential role of the calendarized package in improving patients compliance. However, this study has several limitations that should be considered. The first limitation is in the distribution of patients' age recruited between two groups. The analysis results in Table 2 showed a significant difference in patients' age which can intervene in patients' compliance. Age was confirmed as the independent factor related to nonadherence. Poor compliance in older age, especially the elderly, is associated with the decline in memory, forgetfulness, which was influenced by advertisements and the preference for secret recipes or food therapy [4], [13], [16]. Bigger sample size in further study is needed to minimize the bias caused by the different age profiles between the two groups. In addition, because of the pandemic COVID-19, the compliance measurement was conducted indirectly. Therefore, future research using stricter compliance measurement methods is needed to confirm this finding.

\section{Conclusion}

The application of the calendar on the package indicates the positive impact on the patients' compliance with antibiotics. However, several limitations should be considered. Future research using a bigger sample size and stricter compliance measurement method is needed to confirm this finding.

\section{Acknowledgments}

The authors would like to thank The Ministry of Research and Technology/NationalAgency for Research and Innovation of Indonesia (Kemenristekdikti) for the funding support in the scheme of National Competitive National Research and all the community health centers personnel for the research permission.

\section{References}

1. Wattiheluw $\mathrm{MH}$, Herawati F, Setiasih S, Yulia R. Correlation of knowledge and beliefs to adherence with antibiotic use in adult patients at a private hospital in sidoarjo. Kesmas Natl Public Health J. 2020;15(2):99-104. https://doi.org/10.21109/kesmas. v15i2.2409

2. World Health Organization. High Levels of Antibiotic Resistance Found Worldwide, New Data Shows. Geneva: World Health Organization; 2018.
3. Llor C, Bjerrum L. Antimicrobial resistance: Risk associated with antibiotic overuse and initiatives to reduce the problem. Ther Adv Drug Saf. 2014;5(6):229-41. https://doi. org/10.1177/2042098614554919

PMid:25436105

4. Tong S, Pan J, Lu S, Tang J. Patient compliance with antimicrobial drugs: A Chinese survey. Am J Infect Control. 2018;46(4):e25-9. https://doi.org/10.1016/j.ajic.2018.01.008 PMid:29592834

5. Wibowo R, Soedibyo S. Kepatuhan berobat dengan antibiotik jangka pendek di poliklinik umum departemen ilmu kesehatan anak rumah sakit Dr. cipto mangunkusumo, Jakarta. Sari Pediatri. 2016;10(3):171. https://doi.org/10.14238/sp10.3.2008.171-6

6. Zedler BK, Joyce A, Murrelle L, Kakad P, Harpe SE. A pharmacoepidemiologic analysis of the impact of calendar packaging on adherence to self-administered medications for long-term use. Clin Ther. 2011;33(5):581-97. https://doi. org/10.1016/j.clinthera.2011.04.020

7. Dupclay L, Eaddy M, Jackson J, Raju A, Shim A. Real-world impact of reminder packaging on antihypertensive treatment adherence and persistence. Patient Prefer Adherence. 2012;6:499-507. https://doi.org/10.2147/ppa.s31417 PMid:22927746

8. Sammulia SF, Rahmawati F, Andayani TM. Comparative Pill Box and Medication Chart on The Levels Compliance and Clinical Outcome in Elderly Patients at Batam. J Manag Pharm Pract. 2016;6(4):288. https://doi.org/10.22146/jmpf.358

9. Khoiriyyah A, Ediati A. Pengaruh buku harian untuk meningkatkan kepatuhan pada pasien hipertensi: Studi kuasi eksperimen pada pasien hipertensi. J Empati. 2015;4(1):35-42. https://doi.org/10.53475/jicm.v3i1.74

10. Muljabar SM, Supadmi W. The Influence of Giving Drug Information to Level Compliance for Antibiotic Used in Patients of Acute Respiratory Infection at Community Health Centre Kotagede I Yogyakarta. Pharmaciana. 2014;4(2):143-9. https:// doi.org/10.12928/pharmaciana.v4i2.1571

11. Naibobe DM, Rengga MP. The Effect of Counseling on The Adherence of Antibiotic Used in Acute Respiratory Infection (ARI) Patients at Sikumana Public Health Center. CHMK Pharm Sci J. 2020;3(2):133-7. https://doi.org/10.51352/jim.v4i1.134

12. Lee JK, Grace KA, Foster TG, Crawley MJ, Erowele GI, Sun HJ, et al. How should we measure medication adherence in clinical trials and practice? Ther Clin Risk Manag. 2007;3(4):685-90. PMid:18472991

13. Fernandes M, Leite A, Basto M, Nobre MA, Vieira N, Fernandes $\mathrm{R}$, et al. Non-adherence to antibiotic therapy in patients visiting community pharmacies. Int J Clin Pharm. 2014;36(1):86-91. https://doi.org/10.1007/s11096-013-9850-4 PMid:24101031

14. Schneider PJ, Murphy JE, Pedersen CA. Impact of medication packaging on adherence and treatment outcomes in older ambulatory patients. J Am Pharm Assoc (2003). 2008;48(1):58-63. PMid: 18192132

15. Ahmed NJ. The rate of adherence to antibiotics and reasons for non-adherence among the public. J Pharm Res Int. 2020;32(7):42-7. https://doi.org/10.9734/jpri/2020/v32i730458

16. Kandrotaite $K$, Smigelskas $K$, Janusauskiene $D$, Jievaltas $M$, Maciulaitis R, Briedis V. Development of a short questionnaire to identify the risk of nonadherence to antibiotic treatment. Curr Med Res Opin. 2013;29(11):1555-63. https://doi.org/10.1185/03 007995.2013 .835255

PMid:23952367 